4

\title{
On the larva and the zooid of the pterobranch Rhabdopleura recondita Beli, Cameron and Piraino, 2018 (Hemichordata, Graptolithina)
}

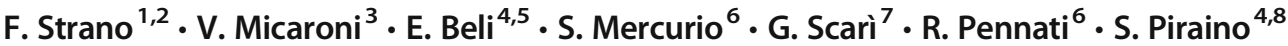 \\ Received: 31 October 2018 / Revised: 29 November 2018 / Accepted: 3 December 2018 \\ (C) Senckenberg Gesellschaft für Naturforschung 2018
}

\begin{abstract}
Hemichordates (Enteropneusta and Pterobranchia) belong to a small deuterostome invertebrate group that may offer insights on the origin and evolution of the chordate nervous system. Among them, the colonial pterobranch Rhabdopleuridae are recognized as living representatives of Graptolithina, a taxon with a rich fossil record. New information is provided here on the substrate selection and the life cycle of Rhabdopleura recondita Beli, Cameron and Piraino, 2018, and for the first time, we describe the nervous system organization of the larva and the adult zooid, as well as the morphological, neuroanatomical and behavioural changes occurring throughout metamorphosis. Immunohistochemical analyses disclosed a centralized nervous system in the sessile adult zooid, characterized by different neuronal subsets with three distinct neurotransmitters, i.e. serotonin, dopamine and RFamide. The peripheral nervous system comprises GABA-, serotonin-, and dopamine-immunoreactive cells. These observations support and integrate previous neuroanatomical findings on the pterobranch zooid of Cephalodiscus gracilis. Indeed, this is the first evidence of dopamine, RFamide and GABA neurotransmitters in hemichordates pterobranchs. In contrast, the lecithotrophic larva is characterized by a diffuse basiepidermal plexus of GABAergic cells, coupled with a small group of serotonin-immunoreactive cells localized in the characteristic ventral depression. It is envisaged the use of $R$. recondita as a novel and easily accessible hemichordate model organism shed light on the evolution of hemichordates and more generally on the origin of deuterostome developmental mechanisms.
\end{abstract}

Keywords Pterobranchia $\cdot$ Life cycle $\cdot$ Nervous system $\cdot$ Neurotransmitter $\cdot$ Development $\cdot$ Metamorphosis

\section{Introduction}

Hemichordata (Bateson, 1885) is a phylum of marine deuterostome invertebrates with a key phylogenetic position (Nielsen 2012). Indeed, recent molecular analyses recognize this taxon as the sister group of Echinodermata within the Ambulacraria
(Bourlat et al. 2006; Cannon et al. 2009; Satoh et al. 2014a). To date, about 130 hemichordate species have been described and grouped into two classes: the free-living Enteropneusta and the sessile Pterobranchia (Tassia et al. 2016). Although all hemichordates share the tripartite body with the anterior prosome, the intermediate mesosome, and the posterior

Communicated by S. Stöhr

R. Pennati

roberta.pennati@unimi.it

S. Piraino

stefano.piraino@unisalento.it

1 Department of Life Sciences, University of Trieste, Via Licio Giorgieri, 34127 Trieste, Italy

2 Department of Biology and Evolution of Marine Organisms, Stazione Zoologica Anton Dohrn Napoli, Villa Comunale, 80121 Naples, Italy

3 School of Biological Sciences, Victoria University of Wellington, Wellington 6140, New Zealand
4 Department of Biological and Environmental Sciences and Technologies, University of Salento, Via Provinciale Lecce-Monteroni, 73100 Lecce, Italy

5 Département de Sciences Biologiques, Université de Montréal, C.P. 6128, Succursale Centre-ville, Montreal, QC H3C 3J7, Canada

6 Department of Environmental Sciences and Policy, University of Milan, Via Celoria, 20133 Milan, Italy

7 Department of Biology, University of Milan, Via Celoria, 20133 Milan, Italy

8 National Inter-University Consortium for Marine Sciences, Piazzale Flaminio, 00196 Rome, Italy 
metasome, each containing single or paired coelomic cavities (Gemmill 1914; Hadfield 1975; Benito and Pardos 1997; Balser and Ruppert 1990), members of the two clades strongly differ in several aspects. Enteropneusts, commonly known as acorn worms, are characterized by a solitary life habit in burrows or under stones from the intertidal to deep-sea zones worldwide (Cameron 2018). Species like Saccoglossus kowalevskii and Ptychodera flava are now regarded as model organisms for the study of deuterostome evolution (Arendt et al. 2008; Fan and Su 2015; Simakov et al. 2015; D'Aniello et al. 2015; Tagawa 2016). Much less is known of pterobranchs, due to their small size and rarity and the limited number of known species (Beli et al. 2018). Therefore, this group has been largely overlooked and poorly investigated (Brown et al. 2008; Smith 2008). However, their occurrence may be much more common than previously thought, having been recently recorded from coastal areas at shallow depths (Beli et al. 2018). Different from the naked free-living enteropneusts, pterobranch zooids are sessile and have a colonial or pseudocolonial life habit (Maletz 2014a), usually dwelling in proteinaceous tubes (tubaria) largely secreted by the cephalic shields of individual zooids (Dilly 1986; Dilly 1988; Maletz and Steiner 2015). They have one to several pairs of filter feeding tentaculated arms growing from the collar, a U-shaped gut, ventrally interconnected (in colonial species) by a thin, organic stolon system (Maletz 2014b; Maletz and Cameron 2016; Beli et al. 2018). Pterobranchia traditionally encompassed two orders: Cephalodiscida and Rhabdopleurida. However, recent phylogenetic analysis highlighted that extant rhabdopleurids are living representatives of graptolites (Mitchell et al. 2013). This led to the redefinition of the Pterobranchia into two major clades: the Graptolithina (including fossil graptolites and extant rhabdopleurid species) and the Cephalodiscida.

The dichotomy between the different life habits of enteropneust worms and pterobranch zooids is remarkably paralleled to the distinct neuroanatomical organizations of the two groups. The nervous system of enteropneusts consists of intraepithelial neural cells whose neurites develop into a basiepidermal nerve plexus, with condensed regions forming the nerve ring in the proboscis, the dorsal nerve cord in the collar and trunk regions, and the ventral nerve cord in the trunk region, interconnected to the dorsal one by a prebranchial nerve ring (Bullock 1945; Knight-Jones 1952; Kaul-Strehlow et al. 2017). Kaul and Stach (2010) recently argued that the collar cord of enteropneusts might work as the centralized nervous system (i.e. where condensed nerve cell bodies and neurites that arise from them are distinctly interrelated by synapses and neuronal integration in a more complex way than elsewhere in the body; see Holland 2003). However, electrical recordings from nerve cords do not bear this out (Pickens 1970; Cameron and Mackie 1996). As for enteropneusts, a basiepidermal nervous system was early recognized in rhabdopleurid pterobranchs but with a dorsal, ganglion-like structure, occurring in the mesosome region and giving rise to distinct nerve branches (Dilly 1975; Benito and Pardos 1997). More recently, an immunohistochemical investigation on the nervous system of Cephalodiscus gracilis showed a serotonergic dorsal brain-like condensation at the base of mesosomal tentacles, associated to peripheral brachial nerves, tentacle nerves and a ventral stalk nerve (Stach et al. 2012). The dorsal localization of the pterobranch mesosomal plexus and of the collar cord of enteropneusts has been interpreted as a symplesiomorphy of hemichordates, supporting the hypothesis that a centralized nervous system already occurred in the last common deuterostome ancestor (Stach et al. 2012). However, the developmental mechanisms underlying the origin of the dorsal brain of adult pterobranchs remains to be elucidated.

The rarity of pterobranch colonies has led to even rarer observations on their life cycle (Stebbing 1970; Dilly 1973; Lester 1988a, 1988b; Sato 2008; Dilly 2014). The discovery of a new pterobranch species, Rhabdopleura recondita Beli, Cameron and Piraino, 2018, in the Mediterranean Sea (Beli et al. 2018) offered the opportunity to investigate its life cycle and to investigate the morphological and neuroanatomical organization of its two life stages, the larva and the adult zooid.

\section{Materials and methods}

\section{Sampling and in vivo observations}

Rhabdopleura recondita colonies were found associated with dead and partially dead colonies of calcareous bryozoans. These were collected by SCUBA diving on rocky precoralligenous substrates, at a depth ranging from 15 to $25 \mathrm{~m}$, during November 2015 in the locality of Torre del Serpe (40 $\left.8^{\prime} 23.54^{\prime \prime} \mathrm{N}, 18^{\circ} 30^{\prime} 31.23^{\prime \prime} \mathrm{E}\right)$ and in March 2016 at Punta Facì (40 $\left.8^{\prime} 5.75^{\prime \prime} \mathrm{N}, 18^{\circ} 31^{\prime} 2.07^{\prime \prime} \mathrm{E}\right)$, Otranto Channel, Italy. Samples were immediately brought to the laboratory and kept in aquaria containing natural seawater at $14{ }^{\circ} \mathrm{C}$. From May to June 2016, additional bryozoan samples were collected in Tricase Porto ( $\left.39^{\circ} 52^{\prime} 52.48^{\prime \prime} \mathrm{N}, 18^{\circ} 25^{\prime} 7.43^{\prime \prime} \mathrm{E}\right)$ by demersal gill nets operated by professional fishermen on submersed ridges from 60 to $70 \mathrm{~m}$ depth in the framework of the project "Biodiversity MARE Tricase" (Micaroni et al. 2018a, 2018b). Animals were brought to the laboratory and then kept in natural seawater aquaria at $21{ }^{\circ} \mathrm{C}$. Dead parts of the collected bryozoans were fragmented with pliers and pointed tools and observed at the stereomicroscope and optical microscopes. Naked zooids were isolated from their tubaria and cleaned, using sharp forceps and acupuncture needles. Swimming larvae of $R$. recondita were captured by glass pipettes. In vivo images were made using a Sony-RX100-I camera superimposed on a Leica MZ6 ocular stereomicroscope. 


\section{Light microscopy and scanning electron microscopy}

For scanning electron microscopy analysis, zooids and larvae were relaxed in $3.5 \% \mathrm{MgCl}_{2}$ in sea water and fixed in $2 \%$ glutaraldehyde in $0.1 \mathrm{M}$ cacodylate buffer and $1.4 \% \mathrm{NaCl}$ for $2 \mathrm{~h}$ at room temperature. Samples were rinsed in cacodylate buffer solution overnight and post-fixed for $1 \mathrm{~h}$ with $1 \%$ osmium tetroxide $\left(\mathrm{OsO}_{4}\right)$. Samples were then dehydrated in ethanol series $(30 \%, 50 \%, 70 \%, 90 \%$, and $100 \%)$. Absolute ethanol was gradually substituted with hexamethyldisilazane ( $\geq 99 \%$ grade; Sigma, Italy). Samples were left to dry, mounted on stabs, covered by a thin pure gold layer (Sputter Coater Nanotech), and observed using a ZEISS LEO-1430 microscope. Standard methods of light microscopy were also employed. Samples (adult zooids and larvae) were pre-fixed with $2 \%$ glutaraldehyde in $0.1 \mathrm{M}$ cacodylate buffer and $1.4 \% \mathrm{NaCl}$ for $2 \mathrm{~h}$ and, after overnight washing in the same buffer, post-fixed with $1 \%$ solution of $\mathrm{OsO}_{4}$ in $0.1 \mathrm{M}$ cacodylate buffer. After standard dehydration in ethanol series $(25 \%, 70 \%, 90 \%$, and $100 \%)$, samples were washed in propylene oxide and embedded in Epon-Araldite 812 resin. Semithin sections (about $0.6 \mu \mathrm{m}$ ) were cut with a Reichert-Jung ULTRACUT E using glass knives, stained with crystal violet and basic fuchsine, and then mounted with Eukitt (Bio Optica). Samples were observed under a Leica light microscope (DMRB model) and photographed using a Leica DFC320 camera and LAS (Leica Application Suite, Leica) software.

\section{Immunohistochemical analysis}

For immunohistochemistry, zooids and larvae were first anesthetized as above described and then fixed in 4\% paraformaldehyde in $0.1 \mathrm{M}$ PBS for $1 \mathrm{~h}$ at room temperature. After triplicate washes in a solution of $0.1 \%$ Tween- 20 in $0.1 \mathrm{M}$ PBS (PBT), samples were processed for double fluorescent immunolocalization. Samples were permeabilized for $20 \mathrm{~min}$ with a solution of $0.25 \%$ Triton $\mathrm{X}$, in PBT $\mathrm{pH} 7.4$, and preincubated for $2 \mathrm{~h}$ at room temperature in 50\% Normal Goat Serum (NGS) previously inactivated at $55{ }^{\circ} \mathrm{C}$ for $30 \mathrm{~min}$. Samples were separately incubated overnight at $4{ }^{\circ} \mathrm{C}$ in a solution of $10 \%$ NGS in PBT with different primary polyclonal antibodies: anti-serotonin, anti-dopamine, anti-GABA (Sigma, Italy), and anti-RF (clone 1773IIIp, kindly provided by Prof. Thomas Leitz, Heidelberg) made in rabbit, diluted 1:500. Thereafter, samples were rinsed several times with PBT, pre-incubated in 50\% NGS, and incubated overnight at $4{ }^{\circ} \mathrm{C}$ with anti-tyrosinated $\alpha$-tubulin antibody (Sigma, Italy) made in mouse, diluted 1:250. Samples were washed three times in PBT and then pre-incubated for $2 \mathrm{~h}$ in $0.1 \%$ bovine serum albumin (BSA; Sigma) dissolved in PBS at room temperature. Each sample was incubated overnight at $4{ }^{\circ} \mathrm{C}$ in the corresponding secondary antibodies: Alexa Fluor 568 Goat
Anti-Mouse IgG Antibody (Life Technology), Alexa Fluor 488 Goat Anti-Rabbit IgG Antibody (Life Technology), both diluted 1:800 in PBS. In some samples, the antibody antityrosinated $\alpha$-tubulin was omitted and filamentous actin was labeled with TRITC-conjugated phalloidin (Sigma, Italy). Nuclei were labeled with DAPI $(20 \mathrm{mg} / \mathrm{ml})$. Specimens were mounted with 1,4-diazabicyclo[2,2,2] octane (DABCO, Sigma, Italy) plus MOWIOL (Sigma, Italy) on microscope slides and examined using a Leica SP2 confocal laser scanning microscope (Leica Microsystems, Heidelberg, Germany), equipped with laser argon/krypton, $75 \mathrm{~mW}$ multiline. A series of "optical sections" attained by scanning wholemount specimens were projected into one image with greater focal depth. The step size of "optical sections" was $1.5 \mu \mathrm{m}$.

\section{Results}

\section{Behaviour and life cycle of Rhabdopleura recondita}

Colonies of Rhabdopleura recondita were found in association with dead skeletal parts of several bryozoan species: Myriapora truncata (Pallas, 1766), Schizoretepora serratimargo (Hincks, 1886), Celleporina caminata (Waters, 1879), Pentapora fascialis (Pallas, 1766), Reptadeonella violacea (Johnston, 1847), Turbicellepora magnicostata (Barroso, 1919). The tubaria of $R$. recondita are composed of smooth creeping tubes lining the natural internal cavities of the bryozoan zooecium, and erect, brownish, and semitransparent tubes, with characteristic annular rings (fuselli), that emerge from the zooecium openings (Fig. 1a, b). The adult zooids of $R$. recondita show the typical rhabdopleurid body organization: a prosome with cephalic shield, a mesosome that encloses the ventral mouth opening and two dorsal feeding arms each with two rows of tentacles (mean number of tentacles for each row, $21 \pm 3$ ), and a metasome with the internal U-shaped digestive tract, the contractile stalk, and the stolon (Fig. 1c, d). The zooids are covered by beating cilia and protrude from their tubes up to the mesosome, extending outwards the two dorsal arms and filter feeding by their ciliated tentacles (Fig. 1e, f). The pterobranch feeding mechanism has been investigated in detail (Stebbing and Dilly 1972; Dilly 1972, 1973) with the identification of a set of feeding characteristics similar to those of the lophophore of bryozoans, brachiopods, and foronids (Halanych 1993).

The pterobranch colony develops from a yellow-coloured, free-swimming larva, spotted with black pigment granules and characterized by a posterior ventral depression (Fig. 1g, h). The distribution of black granules in the larva is not uniform: two symmetric concentrations occur in the dorso-lateral area, corresponding to the areas where the morphogenesis of the dorsal arms will take place, and are absent from the ventral 

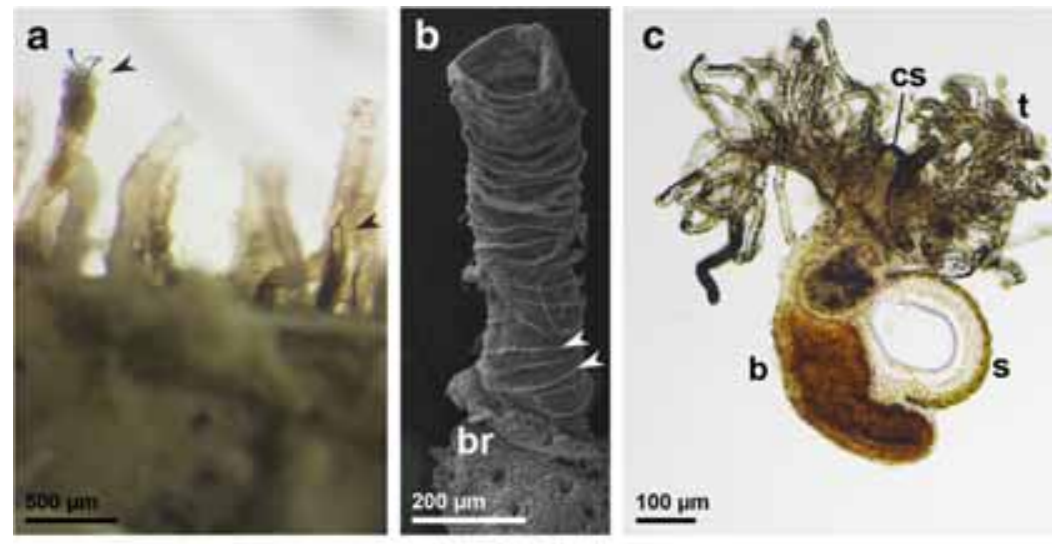

$\underline{100 \mu \mathrm{m}}$
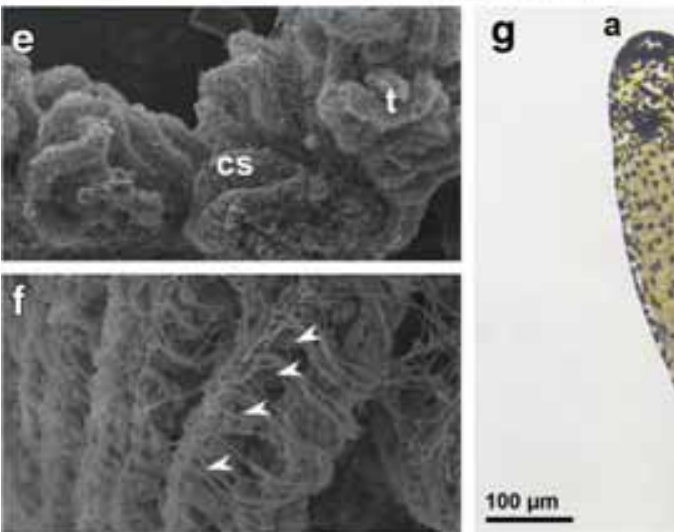

Fig. 1 Overview of Rhabdopleura recondita colony, zooid, and larval morphology. a In vivo colony picture: the semitransparent tubarium protruding from the calcareous bryozoan zooecia, with protruding visible zooids (black arrowheads). b Scanning electron microscope (SEM) image of the tube, characterized by the annular fusellar ridges (white arrowheads). c The zooid out of its tube shows two black nontentacled arm tips, cephalic shield, tentacled arms, metasoma, and contractile stalk. d SEM image of the zooid: the mouth opening is located in between the cephalic shield and the collar. e The two depression. While swimming, the beating cilia rotated around its (antero-posterior) axis. Occasionally, it remained stationary for several minutes, and then it glided over the substrate, using ventral cilia.
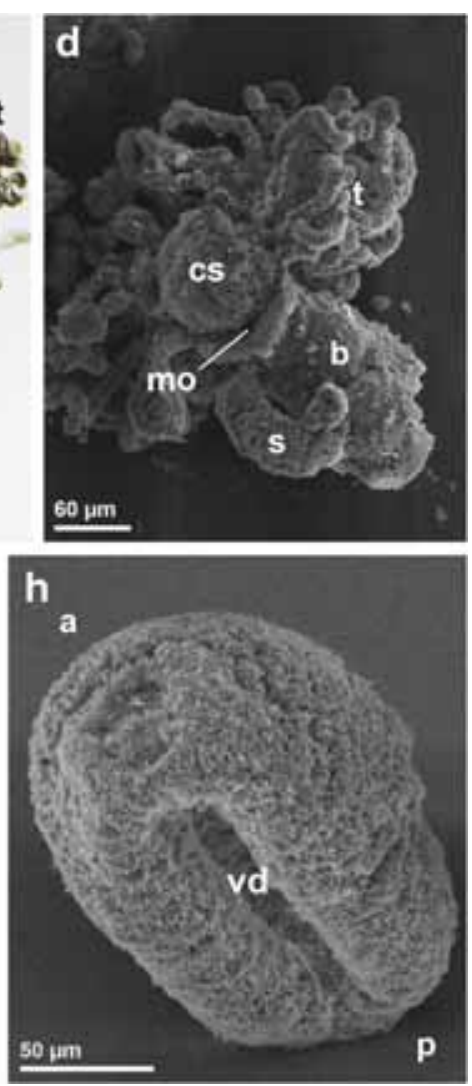

tentacled arms are placed dorsally to the cephalic shield. f Tentacles are lined by longitudinal rows of cilia (arrowheads)for suspension feeding. $\mathbf{g}$ In vivo swimming larva, mounted on microscope slide (dorsal view): the larva is characterized by yellow and dotty black pigmentation. h SEM image of the larva of $R$. recondita (ventral view): the larva is covered by cilia, the characteristic ventral depression appears as a groove. br, bryozoan; b, metasoma; cs, cephalic shield; s, contractile stalk; t, tentacles; a, anterior larval pole; p, posterior larval pole; vd, ventral depression

Once it had found a suitable settlement site inside the calcareous bryozoan zooecium, the larva underwent a gradual metamorphosis through four consecutive stages: (1) secretion of a transparent protective cocoon, the dome; (2) emergence of
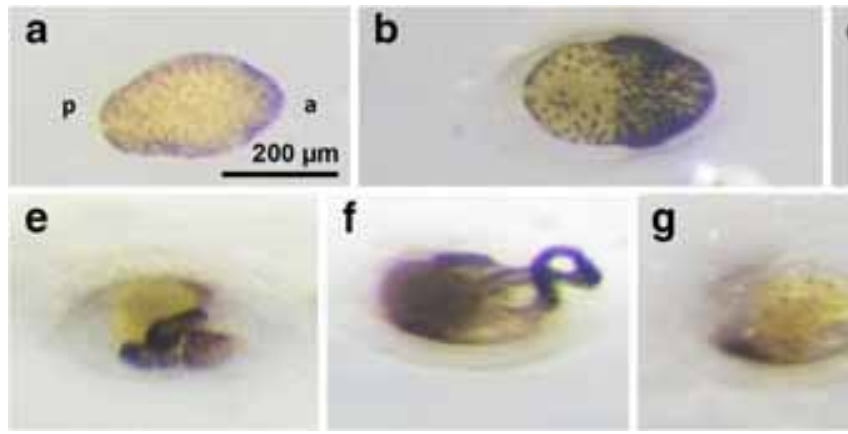

Fig. 2 The metamorphosis of $R$. recondita larva is characterized by four main stages. a Free-swimming larva, settling and $\mathbf{b}$ secreting the dome (arrowhead). At this stage, pigmented cells concentrate at the arm primordia, while $\mathbf{c}$ the ventral depression remains unpigmented. $\mathbf{d}$ Second stage: appearance of cephalic shield and initial formations of

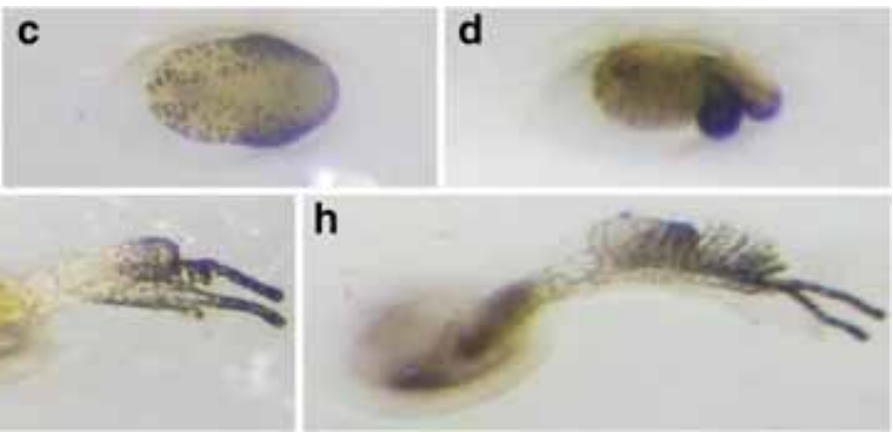

arms in dorso-lateral position. $\mathbf{e}-\mathbf{g}$ Third stage: progressive elongation of the black arms and the contractile stalk. h Final stage: development of ciliated tentacles on the black arms, differentiation of the tripartite body organization, and formation of the opened tube. a, anterior pole; $p$, posterior pole 
Fig. 3 Histological sections of post-settlement $R$. recondita larvae. a Transverse section, median position. The cephalic shield rudiment (csr) is already visible. b Transverse section, posterior. A posterior ciliary turf (pc) and an adhesive organ (ao) are formed. A thin mesothelium (mc), surrounded by a thick epidermis (e), lines the inner body portion filled by yolk-rich endomesodermal cells (em). c, $\mathbf{d}$ Longitudinal sections of advanced post-settlement stage. Endoderm (en) and mesoderm (m) are distinguished as separate tissues. A protective cocoon (c) is secreted (c), paralleled by development of the arms (ab)
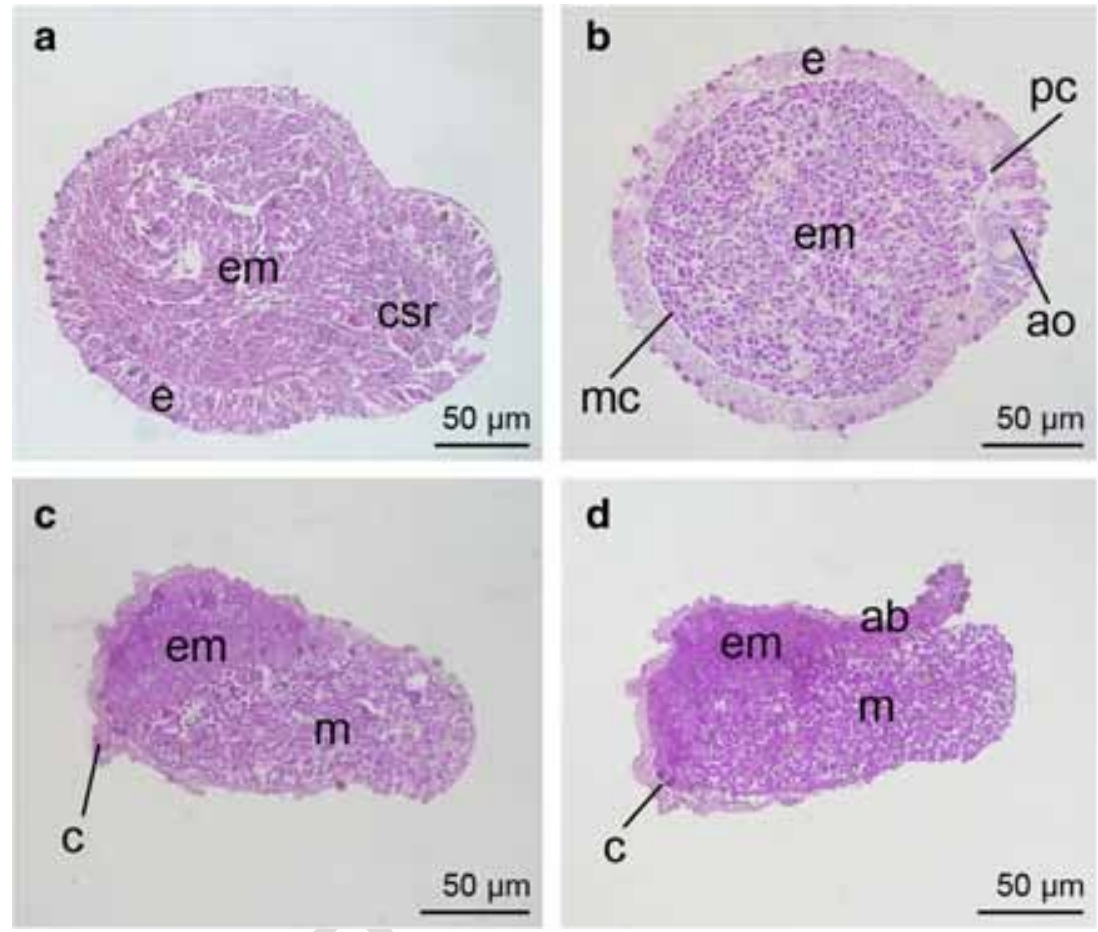

the cephalic shield and of the two symmetric dorsal arm buds; (3) development of the two black tentaculated arms and elongation of the contractile stalk; (4) completion of the paired arms and of their ciliated tentacles, differentiation of the tripartite body organization, and formation of the tube (Fig. 2). The whole metamorphosis (from settlement to full zooid differentiation) takes place in 10 days in laboratory conditions $\left(21^{\circ} \mathrm{C}\right)$. The first pterobranch zooid asexually buds the stolon and gives origin to all the new colonial zooids. Histological sections of the competent larva showed the presence of a central conspicuous mass of endo-mesodermal cells rich inyolk (Fig. 3a, b) and the absence of a gut, characteristic of its lecitotrophic nature. A thin muscular mesothelium lines the coelomic cavity rudiments (Fig. 3a). The epidermis is uniformly thick, except in the posterior area, where elongated mucous-secreting cells constitute the posterior ciliary turf (Fig. 3b). Shortly after settlement, during the earliest stage of metamorphosis, the rudiment of the cephalic shield appears: endodermic derivatives start to differentiate and rise as a mass of cells thicker than those of the surrounding mesoderm (Fig. 3c, d).

\section{Larval and adult nervous system}

Whole-mount immunostaining of zooids with an antibody against tyrosinated $\alpha$-tubulin showed the general arrangement of the nervous system (Fig. 4a). Tyrosinated $\alpha$-tubulin (TyrTub)-positive cells were stained along the two arms forming the brachial nerves. These neurite bundles depart from a concentration of cells localized in the collar region, which showed positive immunoreactivity for different neurotransmitters (Fig. 4a-h). The Tyr-Tub antibody also stained the epidermal cilia, particularly abundant on the tentacles (Fig. 4a). Serotonin (5-hydroxytryptamine, 5-HT)-immunoreactive (IR) cells were the most conspicuous neurons in the collar region (Fig. 4b), dorsally concentrated at the base of the two arms (Fig. 4c). From the collar region, ectodermal serotoninIR fibres run along the entire length of the gut, anteriorly reaching the stalk (Fig. 4d). In $R$. recondita zooids, cells producing neuropeptides with an Arg-Phe-NH2 carboxyterminus (RFamide) were concentrated at the base of tentacles, in the dorsal region of the collar (Fig. 4e). Dopamine (3,4-dihydroxyphenethylamine)-IR cells are localized in the collar region which were distributed along the brachial axis

Fig. 4 Confocal microscope images of the zooids of $R$. recondita. a Ventral view, antibody against tyrosinated $\alpha$-tubulin (red) and DAPIstained nuclei (blue). The brachial nerve (bn) and the ventral chord (vc) are detected. b Lateral view, serotonin immunoreactivity (green) is concentrated (nc) at the base of the tentacled arms. Actin counterstaining with phalloidin (red). c Detail of tentacles ( $t$ ), with regular arrangement of serotonergic cells, (green). $\mathbf{d}$ Lateral view of the zooid, serotoninergic cells (green) mark the ventral chord (vc) along the body (b)of the zooid, at the base of contractile stalk (st); phalloidin counterstaining (red). e RFamide-IR cells (green) are concentrated in the dorsal collar region (co), behind the cephalic disk (cd); phalloidin counterstaining (red). f Dopamine-IR cells (green) are concentrated in the collar region and along the brachial nerves (bn); DAPI-stained nuclei (blue); nervous fibres stained by antibody against tyrosinated $\alpha$ tubulin (red). g GABA-IR cells (green) follow the ciliary rows marked by the alpha tubulin antibody (red); DAPI-stained nuclei (blue). $\mathbf{h}$ Magnification of the tentacle apices showing the distribution of ciliated GABAergic cells 

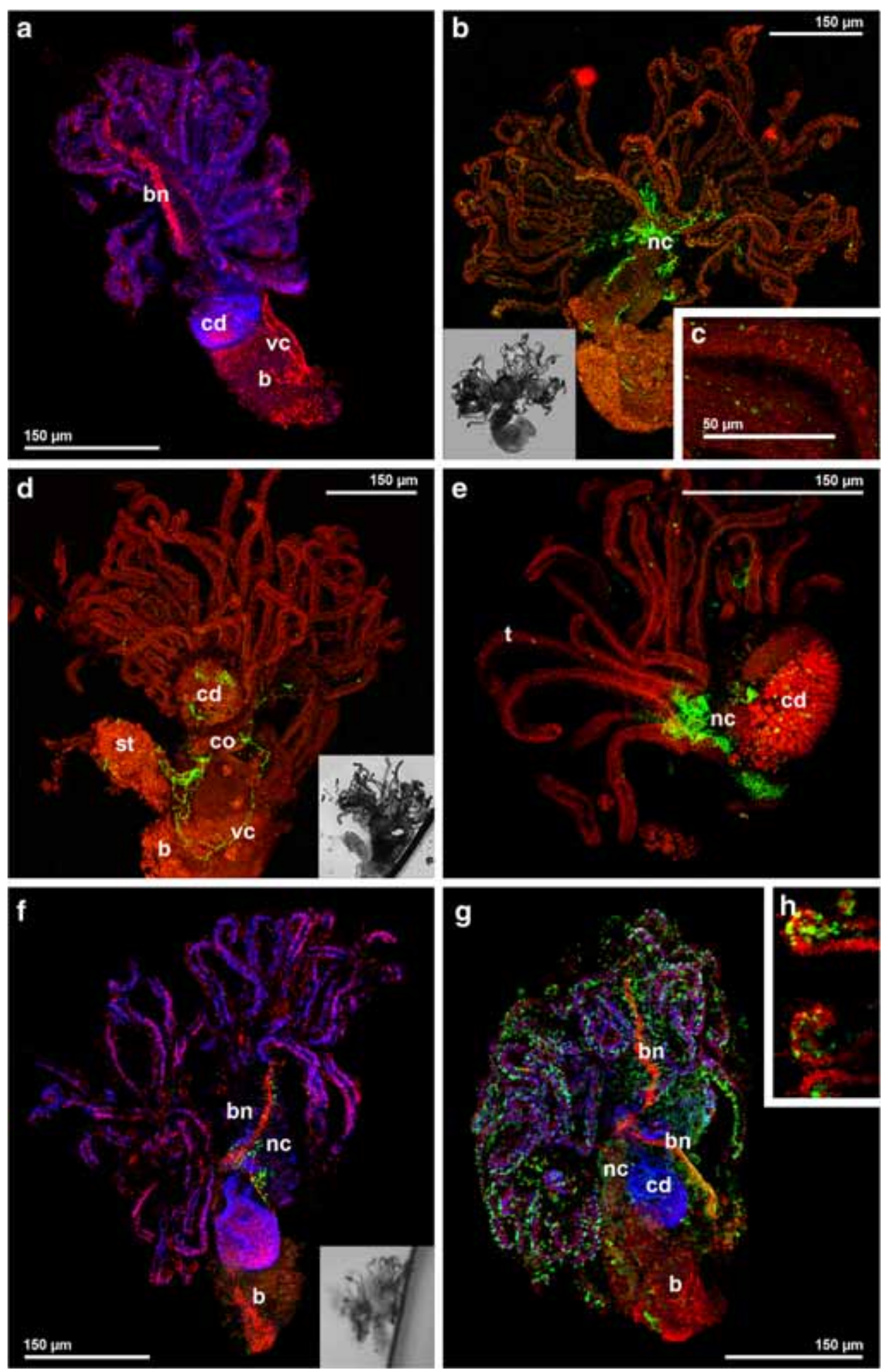

of each of the two feeding arms (Fig. 4f). Numerous GABA

( $\gamma$-aminobutyric acid)-IR cells occur in the epidermis of the tentacles (Fig. 4g). GABAergic cells are not present in the cephalic shield nor in the ventral part of the body, whereas they are present in the posterior collar and in the dorsal midline of the trunk (Fig. 4g). Magnification of the tentacle apices shows that GABA signal is present in spots located along the lateral rows of ciliated cells (Fig. 4h). In the swimming larva of $R$. recondita, basiepidermal GABA cells are widely distributed over the larval body but more concentrated in three areas: two symmetrical zones in correspondence to the two dorsal pigmented regions and a posterior immunoreactive 
concentration in correspondence to the posterior ciliary turf (Fig. 5a). Serotonin-IR interconnected cells are detected in the ventral depression of the larva (Fig. 5b).

\section{Discussion}

Rhabdopleura spp. pterobranchs are traced back to the Middle Ordovician (Sato et al. 2008b; Mitchell et al. 2013; Maletz and Steiner 2015). However, several aspects of their biology, including morphology and lifecycle, are poorly explored (Sato et al. 2008a). Here, novel information is provided on the newly discovered species Rhabdopleura recondita with focus on species substrate preference, life cycle, larval behaviour, metamorphosis, and the nervous system.

So far, hemichordate pterobranchs were generally considered as a rare invertebrate taxon, and for this reason, they remained poorly investigated, in spite of their potential high phylogenetic relevance (Röttinger and Lowe 2012). Colonies of $R$. recondita were found associated with the empty skeletal
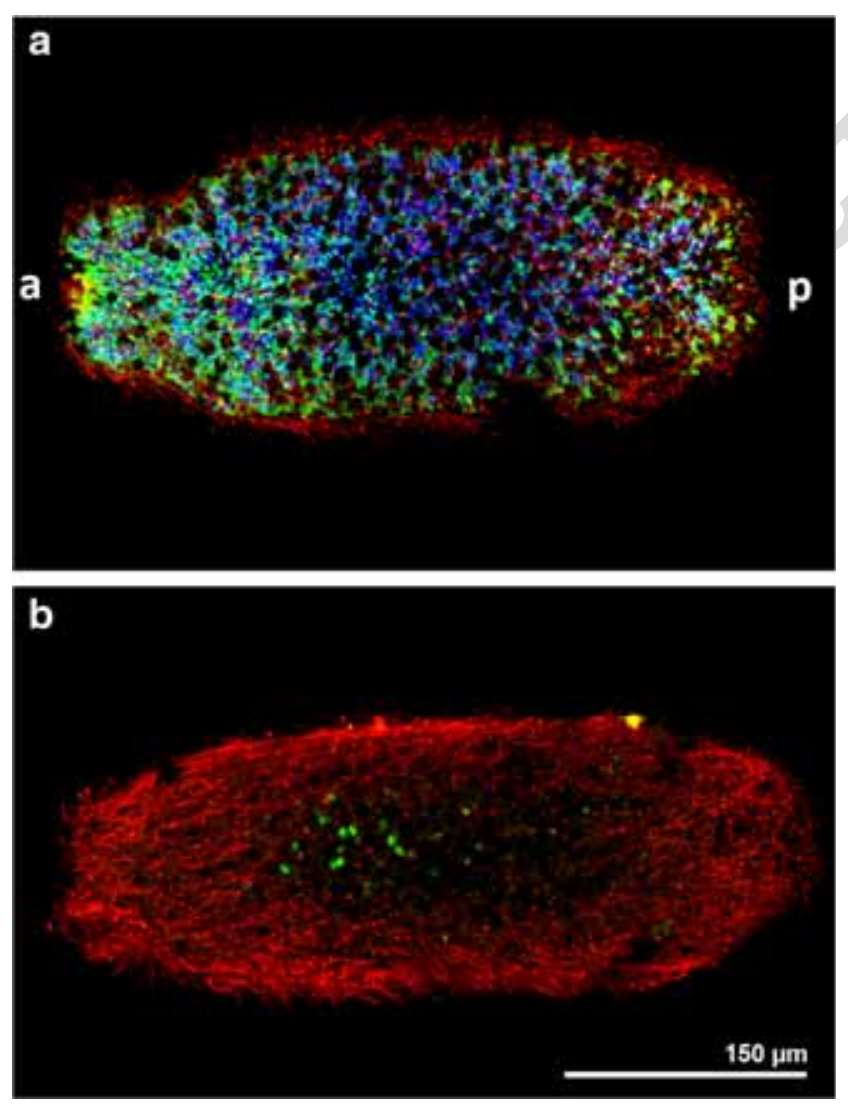

Fig. 5 Confocal microscope images of the larva of $R$. recondita. Posterior part of the larva is on the left. a Dispersed GABA-IR cells (green), condensed in correspondence of the posterior ciliary turf; cilia are stained by tyrosinated $\alpha$-tubulin (red), nuclei are stained by DAPI (blue). b Dispersed serotonin-IR cells (green), in correspondence to the ventral groove. The larva is covered by cilia, stained by antibody against tyrosinated $\alpha$-tubulin (red). Note: the yellow spot in $\mathbf{b}$ is not significant for the present analysis and it is probably dirt attached to larval cilia parts of at least six bryozoan species, witnessing moderate specific requirements in terms of substrate choice preference for its larvae. Given the high frequency and abundance of these bryozoan species in several coastal areas of the Mediterranean Sea (Novosel 2005), it is suggested that pterobranchs may be more common than previously thought across the whole Mediterranean basin.

By standard immunostaining methods commonly applied to marine invertebrates (Pennati et al. 2012), the anatomical complexity that characterizes the nervous system of $R$. recondita has been explored in detail. Three different neuronal subsets characterized by the neurotrasmitters dopamine and serotonin and the RFamide peptide were detected in the centralized nervous system of $R$. recondita, representing the first evidence of the presence of dopamine and RFamide in the central nervous system of Pterobranchia (Fig. 6). GABA-, serotonin-, and dopamine-IR cells were also found in the peripheral nervous system. Interestingly, GABA-positive cells are present throughout the ciliated tentacles, supporting the hypothesis of Dilly (1972) who suggested a nervous control of the ciliary beat. Accordingly, a basiepithelial net of GABA-positive cells is scattered throughout the ciliated ectoderm of the larva, with a posterior concentration in correspondence with the ciliary turf.

The ontogenesis and anatomy of the nervous system are considered key traits to understand species evolution (Holland 2003). According to Garstang (1894), the chordate nervous system evolved by fusion of the ciliary bands of the deuterostome dipleurula larva with the dorsal migration of the circumoral nerve ring. Bateson $(1884,1885)$ argued for the homology between the enteropneust collar cord formation and the chordate neurulation process, also in support of the

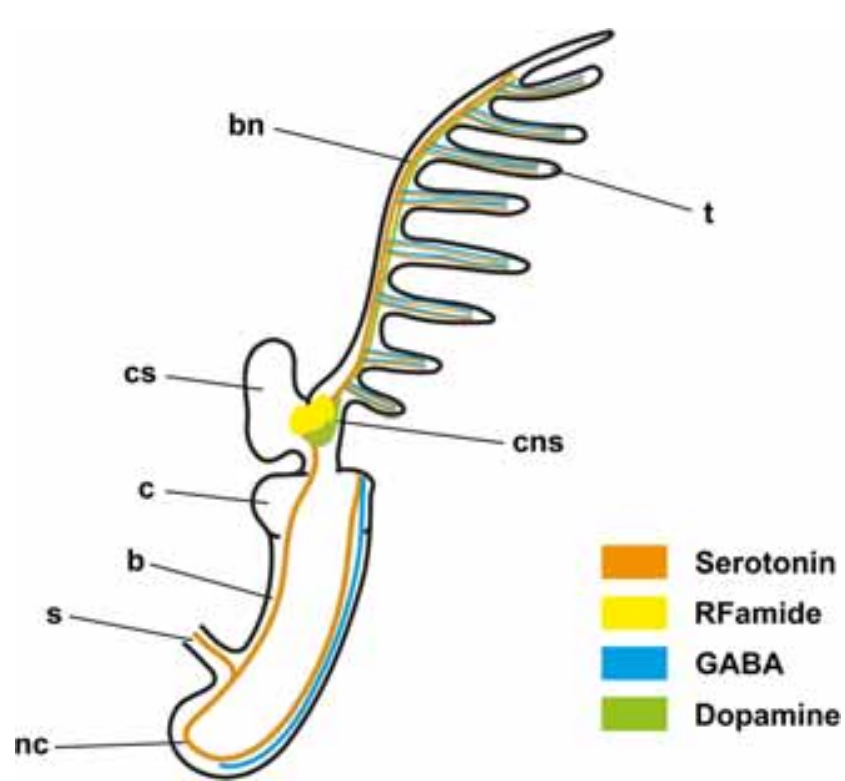

Fig. 6 Schematic overview of the zooid, including the general neuroanatomy, of $R$. recondita, lateral view: cs, cephalic shield; c, collar; s, stalk; t, tentacle; nc, neural cord; cns, central nervous system; bn, brachial nerve 
assumption of homology between the acorn worm stomochord and the chordate notochord. However, the diffuse organization of enteropneust nervous system closely resembles the basiepidermal echinoderm nervous system (Cameron and Mackie 1996), and it appears the stomochord has a closer evolutionary relatedness to the chordate anterior pharynx rather than notochord (Satoh et al. 2014b). In addition, recently, experimental evidence indicates that the neural patterning of enteropneust tubular collar cord is dissimilar to the chordate neural tube (Kaul-Strehlow et al. 2017).

In $C$. gracilis, the presence of synaptic vesicles in the brain has been considered indicative of its function as an integrative centre (Stach et al. 2012). Moreover, serotoninergic cells are concentrated in the anterior portion of the brain and project their processes posteriorly into the trunk, and anteriorly along the tentacles (Stach et al. 2012). Similarly, a prominent concentration of serotonergic neurons occurs in the dorsal part of the collar, at the base of the feeding arms of $R$. recondita. In this region, the presence of dopaminergic and peptidergic (RFamide immunoreactive) neurons is found. Dopamine is an important neurotransmitter for vertebrate and invertebrate central nervous systems and it is involved in memory and movement (Verlinden 2018). RFamide peptides have been demonstrated to be present in the nervous system of vertebrates and invertebrates where they are functional for hormone regulation and behaviour (Osugi et al. 2016). A simple, operational definition of centralized nervous system may be applied to a prominent condensation of diverse neuronal types (Holland 2003); in this framework, the zooid of $R$. recondita shows a centralized nervous system or brain dorsally in the collar, at the base of feeding arms. The evidence of centralized nervous system in the zooid of $R$. recondita corroborates previous findings in C. gracilis (Rehkämper et al. 1987; Stach et al. 2012) supporting the hypothesis that a centralized nervous system was already present in the last common ancestor of deuterostomes (Burke 2011; Nomaksteinsky et al. 2009). Nonetheless, the biochemical diversity and anatomical organization of the nervous system in the pterobranch zooids (compared to the solitary, free-living acorn worms) might be also interpreted as an adaptation to the sessile and colonial filter feeding life habit. Overall, the neuroanatomical disparities found between enteropneusts and pterobranchs and between their larval and adult stages do not enable per se reconstruction of the plesiomorphic state of the nervous system of the hemichordate ancestor.

The larva of $R$. recondita is characterized by interconnected serotoninergic cells localized in a restricted area within the peculiar, unpigmented ventral depression and by the lack of neural centralization. Serotoninergic neurons are also known in tornaria larvae of enteropneusts as well as in echinoderm larvae, both considered homologous and evolved from a common ambulacrarian ancestor (Byrne et al. 2007; KaulStrehlow and Röttinger 2015). Serotoninergic neurons in dipleurula-like larvae are bilaterally associated to the apical organ, interconnected by a neuropil, and involved in the control of ciliary bands (Nezlin and Yushin 2004). Differently, a simple localized network of serotonin-IR cells in the ventral depression of $R$. recondita larva might be related to a morphogenetic role of serotonin as a paracrine signal. Indeed, serotonin is an ancient neurotransmitter found from cnidarians to vertebrates (Hay-Schmidt 2000), known to be involved in mollusc larval metamorphosis (Couper and Leise 1996) and initiation of gastrulation in insects and echinoderms (HaySchmidt 2000) and generally involved in cell proliferation, migration, and apoptosis (Azmitia 2001).

For several invertebrate taxa, it has been proposed that adults arise from larval set-aside cells with a great proliferative capacity (Peterson et al. 1997), although developmental plasticity of differentiated cells is increasingly recognized as a key cellular process contributing to adult formation in indirect developers (Arenas-Mena 2010). The histological sections of the $R$. recondita metamorphosing larva reveal the presence of ectodermic cell proliferation that from the anterior part of the ventral depression gives rise to the cephalic shield (Fig. 3). The observation of the peculiar "stop and go" locomotory behaviour of the larva, with alternation of swimming, resting, and crawling movements over the ventral larval surface, suggests that the ventral depression may also play a relevant role in the selection of the settlement substrate, a hypothesis that needs confirmation by means of additional labelling experiments and ultrastructure investigations.

Overall, it is envisaged that recent advances in genomic resources and developmental genetic tools will increasingly foster the use of pterobranchs, and particularly the highly accessible $R$. recondita, as model organism to add resolution to our understanding of the origin and evolution of hemichordate nervous systems and, more generally, on deuterostome phylogenetic relationships and the origin of the chordates.

Acknowledgements Special thanks to Silvia Messinetti, University of Milan, for laboratory support and to Ittiturismo Anime Sante (Tricase), DWD Diving (Diso), Giorgio Aglieri, and Christian Vaglio that helped us in sampling procedures. The in vivo observations were made at the laboratory of the Avamposto MARE, Tricase Porto (Lecce), in the framework of the project Biodiversity MARE Tricase (http://www. biodiversitymaretricase.org/). The authors thank Prof. Cameron and Prof Maletz for the intensive and fruitful revision of the manuscript.

Data availability All data generated or analyzed during this study are included in this published article.

\section{Compliance with ethical standards}

Ethical approval All applicable international, national, and institutional guidelines for animal testing, animal care, and use of animals were followed by the authors.

Conflict of interest The authors declare that they have no conflict of interest. 
Sampling and field studies All necessary permits for sampling and observational field studies have been obtained by the authors from the competent authorities.

Publisher's Note Springer Nature remains neutral with regard to jurisdictional claims in published maps and institutional affiliations.

\section{References}

Arenas-Mena C (2010) Indirect development, transdifferentiation and the macroregulatory evolution of metazoans. Philos Trans R Soc Lond Ser B Biol Sci 365(1540):653-669. https://doi.org/10.1098/rstb. 2009.0253

Arendt D, Denes AS, Jékely G, Tessmar-Raible K (2008) The evolution of nervous system centralization. Philos Trans R Soc Lond Ser B Biol Sci 363:1523-1528. https://doi.org/10.1098/rstb.2007.2242

Azmitia EC (2001) Modern views on an ancient chemical: serotonin effects on cell proliferation, maturation, and apoptosis. Brain Res Bull 56(5): 413-424. https://doi.org/10.1016/s0361-9230(01)00614-1

Bateson W (1884) Note on the later stages in the development of Balanoglossus kowalevskii (Agassiz), and on the affinities of the Enteropneusta. Proc R Soc Lond B Biol Sci 38:23-30

Bateson W (1885) Memoirs: the later stages in the development of Balanoglossus Kowalevskii, with a suggestion as to the affinities of the Enteropneusta. J Cell Sci 2(S1):81-122. https://doi.org/10. 1098/rspl.1884.0058

Beli E, Aglieri G, Strano F, Maggioni D, Telford MJ, Piraino S, Cameron CB (2018) The zoogeography of extant rhabdopleurid hemichordates (Pterobranchia: Graptolithina), with a new species from the Mediterranean Sea. Invertebr Syst 32(1):100-110. https://doi.org/ 10.1071/IS17021

Benito J, Pardos F (1997) Hemichordata. In: Harrison FW, Ruppert EE (eds) Microscopic anatomy of invertebrates. Wiley, Liss, pp 15-102

Bourlat SJ, Juliusdottir T, Lowe CJ, Freeman R, Aronowicz J, Kirschner M, Lander ES, Thorndyke M, Nakano H, Kohn AB, Heyland A, Moroz LL, Copley RR, Telford MJ (2006) Deuterostome phylogeny reveals monophyletic chordates and the new phylum Xenoturbellida. Nature 444:85. https://doi.org/10.1038/nature05241

Brown FD, Prendergast A, Swalla BJ (2008) Man is but a worm: chordate origins. Genesis 46(11):605-613. https://doi.org/10.1002/dvg. 20471

Bullock TH (1945) The anatomical organization of the nervous system of Enteropneusta. Q J Microsc Sci 86:55-111

Burke RD (2011) Deuterostome neuroanatomy and the body plan paradox. Evol Dev 13(1):110-115. https://doi.org/10.1111/j.1525-142X. 2010.00460.x

Byrne M, Nakajima Y, Chee FC, Burke RD (2007) Apical organs in echinoderm larvae: insights into larval evolution in the Ambulacraria. Evol Dev 9(5):432-445. https://doi.org/10.1111/j. 1525-142X.2007.00189.x

Cameron CB (2018) Treatise on invertebrate paleontology, part V, chapter 2, class Enteropneusta: introduction, morphology, life habits, systematic descriptions, and future research. Treatise Online 109:1-22

Cameron CB, Mackie GO (1996) Conduction pathways in the nervous system of Saccoglossus sp. (Enteropneusta). Can J Zool 74(1):1519. https://doi.org/10.1139/z96-003

Cannon JT, Rychel AL, Eccleston H, Halanych KM, Swalla BJ (2009) Molecular phylogeny of hemichordata, with updated status of deepsea enteropneusts. Mol Phylogenetics Evol 52(1):17-24. https://doi. org/10.1016/j.ympev.2009.03.027

Cannon JT, Swalla BJ, Halanych KM (2013) Hemichordate molecular phylogeny reveals a novel cold-water clade of harrimaniid acorn worms. Biol Bull 225(3):194-204. https://doi.org/10.1086/ BBLv225n3p194

Couper JM, Leise EM (1996) Serotonin injections induce metamorphosis in larvae of the gastropod mollusc Ilyanassa obsoleta. Biol Bull 191(2):178-186. https://doi.org/10.2307/1542921

D'Aniello S, Delroisse J, Valero-Gracia A, Lowe EK, Byrne M, Cannon JT, Halanych KM, Elphick MR, Mallefet J, Kaul-Strehlow S, Lowe CJ, Flammang P, Ullrich-Lüter E, Wanninger A, Arnone MI (2015) Opsin evolution in the Ambulacraria. Mar Genomics 24:177-183. https://doi.org/10.1016/j.margen.2015.10.001

Dilly PN (1972) The structures of the tentacles of Rhabdopleura compacta (Hemichordata) with special reference to neurociliary control. Z Zellforch Microsk Anat Histochem 129(1):20-39. https://doi.org/10.1007/bf00307107

Dilly PN (1973) The larva of Rhabdopleura compacta (Hemichordata). Mar Biol 18(1):69-86. https://doi.org/10.1007/bf00347923

Dilly PN (1975) The pterobranch Rhabdopleura compacta: its nervous system and phylogenetic position. Symp Zool Soc London 36:1-16

Dilly PN (1986) Modern pterobranchs: observations on their behaviour and tube building. Geol Soc 20:261-269. https://doi.org/10.1144/ GSL.SP.1986.020.01.27

Dilly PN (1988) Tube building by Cephalodiscus gracilis. J Zool 216: 465-468. https://doi.org/10.1111/j.1469-7998.1988.tb02442.x

Dilly PN (2014) Cephalodiscus reproductive biology (Pterobranchia, Hemichordata). Acta Zool 95(1):111-124. https://doi.org/10.1111/ azo. 12015

Fan TP, Su YH (2015) FGF signaling repertoire of the indirect developing hemichordate Ptychodera flava. Mar Genomics 24:167-175. https:// doi.org/10.1016/j.margen.2015.07.006

Garstang W (1894) Preliminary note on a new theory of the phylogeny of the Chordata. Zool Anz 17:122-125

Gerhart J, Lowe C, Kirschner M (2005) Hemichordates and the origin of chordates. Curr Opin Genet Dev 15(4):461-467. https://doi.org/10. 1016/j.gde.2005.06.004

Halanych KM (1993) Suspension feeding by the lophophore-like apparatus of the pterobranch hemichordate Rhabdopleura normani. Biol Bull 185(3):417-427. https://doi.org/10.2307/1542482

Hay-Schmidt A (2000) The evolution of the serotonergic nervous system. Proc R Soc Lond B Biol Sci 267:1071-1079. https://doi.org/10. 1098/rspb.2000.1111

Holland ND (2003) Early central nervous system evolution: an era of skin brains? Nat Rev Neurosci 4(8):617-627. https://doi.org/10.1038/ nrn1175

Kaul S, Stach T (2010) Ontogeny of the collar cord: neurulation in the hemichordate Saccoglossus kowalevskii. J Morphol 271(10):1240 1259. https://doi.org/10.1002/jmor. 10868

Kaul-Strehlow S, Röttinger E (2015) In: Wanninger A (ed) Evolutionary developmental biology of invertebrates 6: Deuterostomia. Springer, Berlin, pp 59-90

Kaul-Strehlow S, Urata M, Praher D, Wanninger A (2017) Neuronal patterning of the tubular collar cord is highly conserved among enteropneusts but dissimilar to the chordate neural tube. Sci Rep 7(1):7003. https://doi.org/10.1038/s41598-017-07052-8

Knight-Jones EW (1952) On the nervous system of Saccoglossus cambrensis (Enteropneusta). Philos Trans R Soc Lond Ser B Biol Sci 236:315-354. https://doi.org/10.1098/rstb.1952.0004

Lester SM (1988a) Settlement and metamorphosis of Rhabdopleura normani (Hemichordata: Pterobranchia). Acta Zool 69(2):111120. https://doi.org/10.1111/j.1463-6395.1988.tb00907.x

Lester SM (1988b) Ultrastructure of adult gonads and development and structure of the larva of Rhabdopleura normani (Hemichordata: Pterobranchia). Acta Zool 69(2):95-109. https://doi.org/10.1111/j. 1463-6395.1988.tb00906.x

Maletz J (2014a) The classification of the Pterobranchia (Cephalodiscida and Graptolithina). B Geosci 89(3):477-540. https://doi.org/10. 3140/bull.geosci.1465 
Maletz J (2014b) Hemichordata (Pterobranchia, Enteropneusta) and the fossil record. Palaeogeogr Palaeoclimatol Palaeoecol 398:16-27. https://doi.org/10.1016/j.palaeo.2013.06.010

Maletz J, Cameron CB (2016) Treatise on invertebrate paleontology, part V, chapter 3: introduction to class Pterobranchia Lankester, 1877. Treatise Online 82:1-15

Maletz J, Steiner M (2015) Graptolite (Hemichordata, Pterobranchia) preservation and identification in the Cambrian Series 3. Palaeontology 58(6):1073-1107. https://doi.org/10.1111/pala.12200

Micaroni V, Strano F, Di Franco D, Crocetta F, Grech D, Piraino S, Boero F (2018a) Project "Biodiversity MARE Tricase": a biodiversity inventory of the coastal area of Tricase (Ionian Sea, Italy)-Mollusca: Heterobranchia. Eur Zool J 85(1):180-193. https://doi.org/10.1080/ 24750263.2018.1462413

Micaroni V, Strano F, Di Franco D, Langeneck J, Gravili C, Bertolino M, Costa G, Rindi F, Froglia C, Crocetta F, Giangrande A, Nicoletti L, Medagli P, Zuccarello V, Arzeni S, Bo M, Betti F, Mastrototaro F, Lattanzi L, Piraino S, Boero F (2018b) Project "Biodiversity MARE Tricase": biodiversity research, monitoring and promotion at MARE Outpost (Apulia, Italy). Rend Lincei-Sci Fis Nat 29(3):599-604. https://doi.org/10.1007/s12210-018-0726-3

Mitchell CE, Melchin MJ, Cameron CB, Maletz J (2013) Phylogenetic analysis reveals that Rhabdopleura is an extant graptolite. Lethaia 46(1):34-56. https://doi.org/10.1111/j.1502-3931.2012.00319.x

Nezlin LP, Yushin VV (2004) Structure of the nervous system in the tornaria larva of Balanoglossus proterogonius (Hemichordata: Enteropneusta) and its phylogenetic implications. Zoomorphology 123(1):1-13

Nielsen C (2012) Animal evolution: interrelationships of the living phyla. Oxford University Press, Oxford

Nomaksteinsky M, Röttinger E, Dufour HD, Chettouh Z, Lowe CJ, Martindale MQ, Brunet JF (2009) Centralization of the deuterostome nervous system predates chordates. Curr Biol 19(15):1264 1269. https://doi.org/10.1016/j.cub.2009.05.063

Novosel M (2005) Bryozoans of the Adriatic Sea. Denisia 16:231-246

Osugi T, Son YL, Ubuka T, Satake H, Tsutsui K (2016) RFamide peptides in agnathans and basal chordates. Gen Comp Endocrinol 227:94 100. https://doi.org/10.1016/j.ygcen.2015.06.012

Pennati R, Dell'Anna A, Zega G, De Bernardi F (2012) Immunohistochemical study of the nervous system of the tunicate Thalia democratica (Forsskal, 1775). Eur J Histochem 56(2):16. https:// doi.org/10.4081/ejh.2012.e16

Peterson KJ, Cameron RA, Davidson EH (1997) Set aside cells in maximal indirect development: evolutionary and developmental significance. BioEssays 19(7):623-631. https://doi.org/10.1002/bies. 950190713

Rehkämper G, Welsch U, Dilly PN (1987) Fine structure of the ganglion of Cephalodiscus gracilis (Pterobranchia, Hemichordata). J Comp Neurol 259(2):308-315. https://doi.org/10.1002/cne.902590210

Röttinger E, Lowe CJ (2012) Evolutionary crossroads in developmental biology: hemichordates. Development 139(14):2463-2475. https:// doi.org/10.1242/dev.066712

Sato A (2008) Seasonal reproductive activity in the pterobranch hemichordate Rhabdopleura compacta. J Mar Biol Assoc UK 88(5): 1033-1041. https://doi.org/10.1017/S0025315408001604
Sato A, Bishop JD, Holland PW (2008a) Developmental biology of pterobranch hemichordates: history and perspectives. Genesis 46(11):587-591. https://doi.org/10.1002/dvg.20395

Sato A, Rickards B, Holland PW (2008b) The origins of graptolites and other pterobranchs: a journey from 'Polyzoa'. Lethaia 41(4):303316. https://doi.org/10.1111/j.1502-3931.2008.00123.x

Satoh N, Rokhsar D, Nishikawa T (2014a) Chordate evolution and the three-phylum system. Proc R Soc B 281:20141729. https://doi.org/ 10.1098/rspb.2014.1729

Satoh N, Tagawa K, Lowe CJ, Yu JK, Kawashima T, Takahashi H, Ogasawara M, Kirschner M, Hisata K, Su YH, Gerhart J (2014b) On a possible evolutionary link of the stomochord of hemichordates to pharyngeal organs of chordates. Genesis 52(12):925-934. https:// doi.org/10.1002/dvg.22831

Simakov O, Kawashima T, Marlétaz F, Jenkins J, Koyanagi R, Mitros T, Hisata K, Bredeson J, Shoguchi E, Gyoja F, Yue J, Chen Y, Freeman RM, Sasaki A, Hikosaka-Katayama T, Sato A, Fujie M, Baughman KW, Levine J, Gonzalez P, Cameron C, Fritzenwanker JH, Pani AM, Goto H, Kanda M, Arakaki N, Yamasaki S, Qu J, Cree A, Ding Y, Dinh HH, Dugan S, Holder M, Jhangiani SM, Kovar CL, Lee SL, Lewis LR, Morton D, Nazareth LV, Okwuonu G, Santibanez J, Chen R, Richards S, Muzny DM, Gillis A, Peshkin L, Wu M, Humphreys T, Su Y, Putnam NH, Schmutz J, Fujiyama A, Yu J, Tagawa K, Worley KC, Gibbs RA, Kirschner MW, Lowe CJ, Satoh N, Rokhsar DS, Gerhart J (2015) Hemichordate genomes and deuterostome origins. Nature 527(7579):459. https://doi.org/10. 1038 /nature 16150

Smith AB (2008) Deuterostomes in a twist: the origins of a radical new body plan. Evol Dev 10(4):493-503. https://doi.org/10.1111/j.1525142X.2008.00260.x

Stach T, Gruhl A, Kaul-Strehlow S (2012) The central and peripheral nervous system of Cephalodiscus gracilis (Pterobranchia, Deuterostomia). Zoomorphology 131(1):11-24. https://doi.org/10. 1007/s00435-011-0144-x

Stebbing ARD (1970) Aspects of the reproduction and life cycle of Rhabdopleura compacta (Hemichordata). Mar Biol 5(3):205-212. https://doi.org/10.1007/bf00346908

Stebbing ARD, Dilly PN (1972) Some observations on living Rhabdopveura Compacta (Hemichordata). J Mar Biol Assoc U.K 52(2):443-448. https://doi.org/10.1017/S0025315400018804

Swalla BJ, Smith AB (2008) Deciphering deuterostome phylogeny: molecular, morphological and palaeontological perspectives. Philos Trans R Soc Lond Ser B Biol Sci 363:1557-1568. https://doi.org/ $10.1098 /$ rstb.2007.2246

Tagawa K (2016) Hemichordate models. Curr Opin Genet Dev 39:71-78. https://doi.org/10.1016/j.gde.2016.05.023

Tassia MG, Cannon JT, Konikoff CE, Shenkar N, Halanych KM, Swalla BJ (2016) The global diversity of Hemichordata. PLoS One 11(10): 0162564. https://doi.org/10.1371/journal.pone.0162564

Verlinden H (2018) Dopamine signalling in locusts and other insects. Insect biochemistry and molecular biology. Insect Biochem Mol Biol 97:40-52. https://doi.org/10.1016/j.ibmb.2018.04.005 